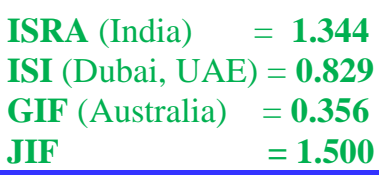
SIS (USA)
$=0.912$
РИНЦ $($ Russia $)=0.179$
ESJI (KZ)
$=1.042$
SJIF $($ Morocco $)=\mathbf{2 . 0 3 1}$

\section{International Scientific Journal Theoretical \& Applied Science}

Ozoda Jalolitdinovna Nishanova

$\mathrm{PhD}$, assistant of professor of the Basics of spirituality and religious issues chair The Mirzo Ulugbek National University of Uzbekistan ozoda.estetika@mail.ru

Year: $2015 \quad$ Issue: 09 Volume: 29

Published: $30.09 .2015 \quad$ http://T-Science.org

SECTION 30. Philosophy.

\title{
HUMAN ORIGINS AND NATIONAL FEATURES OF THE UZBEK ETHNIC CULTURE
}

\author{
Abstract: In given article national and universal human values inherent to the Uzbek people, in some legends, \\ epics, national holidays, traditions and customs are considered. \\ Key words: national features, universal human values, ethnic culture of the Uzbek people, folklore, epics, \\ national traditions, customs, holidays. \\ Language: English \\ Citation: Nishanova OJ (2015) HUMAN ORIGINS AND NATIONAL FEATURES OF THE UZBEK \\ ETHNIC CULTURE. ISJ Theoretical \& Applied Science 09 (29): 124-126. \\ Soi: http://s-o-i.org/1.1/TAS-09-29-24 Doi: crossef http://dx.doi.org/10.15863/TAS.2015.09.29.24
}

In the fundament of study of national and human features of ethnic culture, in our opinion, is advisable to put aesthetic value. The most significant aesthetic value in the Uzbek ethnic culture - a harmony of beauty and morality. The beauty, generosity, humanism are expressed in the Uzbek folk art as a unique aesthetic values. This can be seen in the oral folklore, folk songs and chants, folk proverbs and literary works.

Let's refer to the well-known epos (dastan) of the "Alpamysh". Famous researcher K.Yuldashev writes: "For understanding the nation, we need to know its spirit. The epos (dastan) of the "Alpamysh" is an incredible work of art to express emotional, moral and aesthetic world of the Uzbek people. Because the work is extremely finely displayed peculiar to the Uzbek way of thinking, ways of upbringing and aesthetic comprehension of the world, the manner of decision making... In our opinion, in the spotlight of the dastan are problems of influence on the destiny of man such quality like ignorance. The piece is created not to the listener is made from the narrative the specific findings; this is large-scale, exciting and generalizing work. Indeed, the "Alpamysh" was not created, but retold or vocalized. Because feelings, sensations, emotions, peculiar characters of the dastan are in the blood of the great Turkic peoples. Spiritual exploits, moral feelings of the ancient representatives of the Turkic peoples, soaked with mother's milk for their children, worried about their souls, were on everyone's lips.
And it was sung. It was necessary to chant the fate of the great hero - Alpamysh. And it was impossible not to sing" $[1,28]$. But it was the chanting not for mere pastime, not just for fun, but the chanting of the great moral and aesthetic values, which occupies a special place in the soul and destiny of people.

Another aesthetic side of the national features of the Uzbek ethnic culture is the exaltation of beauty, nobility and courage as ideal. Whatever folk tale or dastan you have not taken, the main hero is always portrayed as a handsome man, endowed with courage and fearlessness. This noble dignity in the artistic-aesthetic image is transformed into a social ideal, which are equal to and sought by generations. In folklore, the beauty, the charm, the elegance of the main hero is depicted as somewhat exaggerated, hyperbolizing. This is expressed in relation to the hero, his superiority among all other characters, bringing him to the forefront of the narrative. In romantic dastans, tales and songs the image of the characters is beautiful, shapely, comely, and young men in love - fearless, courageous, selfless seeking their loved ones is the main artistic device. This beauty, kindness, charming grace, become the nobility of a person of the main character creates in the reader's eye a perfect image. In this way embodied the aspirations, the hopes, the ideal of the nation and its greatness.

It should also be noted that people in the aesthetic evaluation of beauty, kindness face and figure of a hero absolutely not charming by this 
external portrait. External beauty is only a reflection of noble virtues, lofty goals. None of the characters do not like their appearance, like Narcissus of the Greek legend, are not separated from their Motherland and its worries. Folk heroes of their noble deeds, love of country and family, in the devotional service of them create a socio-aesthetic ideal.

National features of the Uzbek ethnic culture are reflected in the national character. The Uzbek national character, according to famous researcher M.Kuranov, consists almost of one thousand qualities. "Each stage in the life of the nation leaves its own trace in it character. The more long and difficult the path, then the deeper it is reflected in the features and character of the nation" [2, p.31]. These positive qualities of national character can be found in varying degrees in almost all forms and types of folk culture. For example, the Navruz is aimed at the glorification inherent in our people hard work, on the formation of the youth labour skills; the "Gul sayli" (flower festival), education of love to the native nature, its beauty; "Kovun sayli" (feast of melons) on the chanting of the results of labor, which allows people to enjoy the juicy fruits of their native land. In the Navruz (one of the national holidays), the Uzbeks put on a festive table a variety of dried fruits and other treats. On the festive table was definitely a big bowl of water, where they had gathered the herbs. This custom was hoped that the New Year will be abundant water and crops. And in general, the basis of all traditions of the Navruz is the only desire of the people to the new year was high-yielding and abundant. The great thinker of the East Omar Khayyam in his book "Navruz-name" specially dedicated to this feast, wrote: "If everyone will celebrate Navruz in joy and gladness, inevitably in the new year until the next Navruz of his life will be held in joy and gladness" [3, p.36].

Folk culture is durable thanks to the combination therein of universal human values and national features. It is a universal human origin turns conservatism into the ethnic culture in a positive reality. Traditions, traditional morality, politeness, behavior in society, norms of existence, which is deeply rooted in the soul, the lifestyle and mentality of the people and turned into historical and cultural paradigm - no matter how conservative they may seem to other cultures, if they are not against humanity, not calling for killing, looting and violence, can be evaluated positively. It's not deal with that traditions are ancient, far behind the modern life, stable, always recurring phenomenon. Such traditions teach people to live in harmony and peace with society, not to put their interests above the interests of society. This, of course, a positive phenomenon. However, if those traditions are contrary to universal values, deny them, prevent a person to live freely and exercise their creative ideas, it leads to negative and even tragic consequences.

Universal human origin in the Uzbek ethnic culture - especially in its humane ideas, in the expression of these ideas through artistic methods and techniques. The exaltation of man, his beauty and virtues, the formation of his needs to look to the future with hope is a moral-aesthetic value of popular culture.

Universal human values reflected in the ideas and plots of literary works, is the friendly relations and integration between peoples, nations and states. Distribution of the dastan "Alpamysh" among all the Turkic peoples, the presence in folklore of almost all nations of subjects, glorifying the friendship of representatives of different nations, show that national culture has always been influenced by the ideas of integration. The isolationism was not typical of folk cultures phenomenon, and international relations and cooperation contributed to the ethnocultural processes of human motives, themes, aesthetic ideal [4, p.16].

Universal human aesthetic values in the Uzbek culture are the result of cultural ties of the Uzbek people with other fraternal peoples, especially peoples of the Central Asia. The proximity of people and their cultures visible not only in some subjects, aesthetic images and ideals, but in the whole works, folk songs, chants, games, and crafts. For example, the dastan "Oshiq Garib va Shahsanam" ("Lover Gharib and Shahsanam") is present in the Uzbek, and in the Turkmen oral folk art, "The Khorezm lyazgi" (dance) is with us, and the Azerbaijanis. Blue, green paints in the ornament found in the Uzbek, the Tajik, and the Kirghiz peoples. Red and octagonal patterns of the Turkmen carpets are often used by the Azerbaijanis and the Turks.

So, many artistic and aesthetic images and stories in the Uzbek ethnic culture were formed in the result of a long socio-historical development and cultural integration. So, the peoples of our region, without comments and translation understand the culture, traditions and artistic and aesthetic thoughts, ideas each other, to easily distinguish them from the ethnic cultures of other peoples. Emotion and plain mischievous songs, the grace of movements in dance, the rich shades and patterns of the imitation of nature when it comes to picking color, the epic and polystylistics in folklore, openness and syncretism of folk holidays and performances - this is art-aesthetic originality of the culture of the peoples of our region.

On the formation of national and universal human features of the Turkic ethnic culture influenced by other factors, such as the naturalgeographical environment, the uniqueness of lifestyle, social relations, and especially the occupation of the ethnic group. These factors could affect the socio-cultural life of man, nation and the world. Therefore, in the culture of peoples living in 


\begin{tabular}{|c|c|c|c|c|c|}
\hline Impact Factor: & $\begin{array}{l}\text { ISRA (India) } \\
\text { ISI (Dubai, UAF } \\
\text { GIF (Australia) } \\
\text { JIF }\end{array}$ & $\begin{array}{l}=1.344 \\
=0.829 \\
=0.356 \\
=1.500\end{array}$ & $\begin{array}{l}\text { SIS (USA) } \\
\text { PИНЦ (Russia } \\
\text { ESJI (KZ) } \\
\text { SJIF (Morocco }\end{array}$ & $\begin{array}{l}=0.912 \\
=0.179 \\
=1.042 \\
=2.031\end{array}$ & ICV (Poland) \\
\hline
\end{tabular}

different regions but with similar natural and geographical environment, a lot of similarity, proximity [5, p.38-41]. But we should not dwell an attention on the factors leading to the isolation of ethnic cultures. No matter how necessary philosophical study of facets of the national identity, of practical importance is also the identification of universal human values, the search for artistic and aesthetic means of the integrating of ethnic cultures.

\section{References:}

1. Juldashev K (2002) “Alpomish" talқinlari. Tashkent: Ma\#navijat, 2002.

2. Kuronov M (2005) Y̌zbek harakteri va millij ғoja. -Tashkent: Ma\#navijat, 2005.

3. Koraboev UH (2002) Ўzbek halқi bajramlari. Tashkent: Shark, 2002.

4. Muhitdinova DM (2005) Nacional'naja jesteticheskaja kul'tura: samobytnost' i problemy razvitija (social'no-filosofskij aspekt). Avtoref. diss. kand. filos. nauk. - Tashkent: 2005.

5. Klakhon K (1998) Zerkalo dlja cheloveka // Vvedenie $\mathrm{v}$ antropologiju. - SPb.: Evrazija, 1998.

6. Tojnbi A (1991) Postizhenie istorii. -M.: Progress, 1991.
7. Asқarov A (2007) Ўzbek halқining jetnogenezi va jetnik tarihi. - Toshkent: Universitet, 2007.

8. Sajjid Muxammad Hotamij (2003) Islom tafakkuri tarihidan. -Toshkent: Minxozh, 2003.

9. Abu Nasr Forobij (1993) Fozil odamlar shaxri. Toshkent: Abdulla Kodirij nomidagi Наһқ merosi nashrijoti, 1993.

10. Abdullaev I (1968) Berunij va uning "Kadimgi halқlardan қolgan jodgorliklar" asari // Abu Rajhon Berunij. Tanlangan asarlar. -Toshkent: Fan, 1968. -T.1.

11. Gerder IG (1977) Idei k filosofii istorii chelovechestva. -M.: Nauka, 1977.

12. (1986) Nazyvat' veshhi svoimi imenami. Programnye vystuplenija masterov zapadnoevropejskoj literatury XX veka. - M.: Progress, 1986. 